\title{
KEGIATAN PRACTICAL LIFE: UPAYA PENANAMAN KEMANDIRIAN PADA ANAK USIA 3-4 TAHUN
}

\author{
Adinda Rizki Aprilia ${ }^{1}$, Rohita $^{1}$ \\ ${ }^{1}$ Program Studi Pendidikan Guru Pendidikan Anak Usia Dini, Fakultas Psikologi dan Pendidikan, \\ Universitas Al Azhar Indonesia, Jalan SisingamangarajaKebayoran baru, Jakarta Selatan, 12110 \\ Penulis untuk korespondensi/E-mail: rohita@uai.ac.id
}

\begin{abstract}
Abstak - Penelitian ini bertujuan untuk menggambarkan kegiatan practical life sebagai upaya dalam menanamkan kemandirian pada anak usia 3-4 tahun, mencakup perencanaan, pelaksanaan, serta penilaiannya. Penelitian yang dilakukan di KB Islam Al Azhar 17 Bintaro dengan kepala sekolah,2 guru kelas, dan 22 anak sebagai sumber data ini menggunakan metode penelitian kualitatif dengan pendekatan kualitatif deskriptif. Pengumpulan data dilakukan menggunakan teknik wawancara,observasi dan dokumentasi. Model Miles and Huberman digunakan untuk melakukan analisis data yangmencakup tahapan reduksi data, display data, dan penarikan kesimpulan. Hasil penelitian menunjukan bahwa kegiatanpractical life untuk menanamkan kemandirian anak usia 3-4 tahun di KB Islam Al Azhar 17 Bintaro dilakukan dengan membuat perencanaan kegiatan practical life dan mencantumkannya dalam RPPM dan RPPH, memberikan kegiatan berupa membuka dan menutup pakaian; membawa cangkir, piring, dan nampan; serta membuka dan menutup pintu. Metode yang digunakan adalah metode praktek langsung, dengan menggunakan media berupa benda sesungguhnya yaitu bingkai pakaian dengan resleting, perekat, dan kancing; cangkir, piring, nampan, serta pintu kelas. Penilaian terhadap capaian kemandirian anak dilakukan menggunakan teknik observasi dengan ceklist.
\end{abstract}

\section{Kata Kunci: Kegiatan practical life, kemandirian, anak usia 3-4 tahun}

Abstract - This study aims to describe practical life activities as an effort to instill independence in children aged 3-4 years, including planning, implementation, and assessment. The research was conducted at KB Islam Al Azhar 17 Bintaro with the principal, 2 classroom teachers, and 22 children as sources of this data using qualitative research methods with a descriptive qualitative approach. Data was collected using interview, observation and documentation techniques. Data analysis was carried out using the Miles and Huberman model including the stages of data reduction, data display, and drawing conclusions. The results showed that practical life activities to instill independence in children aged 3-4 years in KB Islam Al Azhar 17 Bintaro were carried out by planning practical life activities and including them in the RPPM and RPPH, providing activities in the form of opening and closing clothes with zipers, adhesives, and button; carry cups, plates, and trays; and opening and closing doors. The method used is a direct practice method, using media in the form of real objects, namely clothing frames; cups, plates, trays, and classroom doors. The assessment of the achievement of children's independence is carried out using observation techniques with checklists.

Keywords: practical life lesson, independency, children age 3-4 year old 


\section{PENDAHULUAN}

$\mathrm{P}$ endidikan anak usia dini merupakan pendidikan pertama yang didapatkan anak dalam mengembangkan berbagai aspek perkembangannya anak seperti, nilai agama dan moral, fisik motorik, kognitif, bahasa, sosial emosional dan seni. Pendidikan anak usia dini dapat dilaksanakan melalui 3 jalur yaitu pendidikan formal, pendidikan non formal, dan pendidikan informal. Salah satu lembaga Pendidikan Anak Usia Dini pada jalur non formal adalah Kelompok Bermain (KB) yang merupakan pendidikan anak usia 3-4 tahun atau disebut dengan anak usia prasekolah dan sebagai wadah yang berfungsi untuk membantu pertumbuhandan perkembangan anak agar anak memiliki kesiapan dalam memasuki pendidikan lebih lanjut khususnya jenjangTaman Kanak-kanak.

Pendidikan yang diberikan kepada anak melalui Kelompok Bermain diantaranya adalah untuk dapat membantu meletakkan dasar ke arah perkembangan sikap, pengetahuan, keterampilan dan daya cipta yang diperlukan oleh anak dalam menyesuaikan diri dengan lingkungannya serta untuk pertumbuhan dan perkembangan selanjutnya (Parinduri, 2012). Salah satu perkembangan sikap yang dapat dikembangkan yaitu kemandirian.Menurut Noordiati (2018) Kemandirian merupakan kemampuan untuk berusaha dan berupaya dengan diri sendiri ataupun kemampuan untuk memikirkan, merasakan dan melakukan sesuatu sendiri dan tidak bergantung pada orang lain. Dan,kemandirian dapat berkembang dengan baik jika diberikan kesempatan melalui latihan yang dilakukan secara terus menerus dan dilakukan sejak dini (Larasati, 2018).

Kemandirian dapat diberikan dalam bentuk pembelajaran sehingga memberi makna dan pengalaman bagi pembelajar. Yamin \&Sanan (2012) mengartikan pembelajaran adalah suatu proses membangun situasi, serta kondisi belajar melalui penataan pelaksanaan komponen tujuan pembelajaran, materi, metode, kondisi, media, waktu, dan evaluasi yang tujuannya adalah pencapaian hasil belajar anak. Dan, dari kegiatan pembelajaran yang memberikan pengalaman diharapkan akan terjadi perubahan perilaku (Houver, Holmes, \& Moors, 2013).Agar pembelajaran yang diberikan sesuai makna dan mencapai tujuan yang diharapkan maka pembelajaran harus disajikan secara interaktif, inspiratif, menyenangkan, menantang, dan memotivasi peserta didik untuk berpartisipasi aktif, serta memberikan ruang yang cukup (Permendikbud No. 137 Tahun 2014) termasuk untuk kemandirian anak. Salah satu pembelajaran yang dapat diberikan untuk menanamkan kemandirian pada anak dengn cara yang diharapkan tersebut diantaranya melalui kegiatan practical life.

Menurut Rantina (2015),practical life adalah suatu kegiatan kehidupan sehari-hari secara langsung dalam proses pembelajaran pembekalan keterampilan hidup (life skill) pada anak dalam peningkatan kemandirian anak. Sedangkan Morisson (2012:111), menuliskan bahwapractical life merupakan kegiatan yang menekankan aktifitas motorik sehari-hari, seperti berjalan dari satu tempat ke tempat yang lain dalam sikap yang tertib, membawa benda seperti baki dan kursi, mempelajari ketrampilan perawatan diri, dan melakukan aktifitas praktis lainnya.

Adapun pembelajaran practical life untuk anak usia 3-4 tahun menurut Kusumo (2016), adalah memindahkan kancing menggunakan telapak tangan, memindahkan air menggunakan spons, menuang kacang hijau menggunakan dua gelas yang identik, meronce, mencuci tangan sendiri, buka tutup berbagai jenis wadah, menyusun peralatan makan di meja, menyisih hidung, memindahkan benda menggunakan sendok, mencocokan dan menggulung kaus kaki, melipat, memasang sekrup.

Untuk pelaksanaannya, pactical life dapat dilakukan dengan berbagai metode seperti Pengubahan Perilaku (Behavior modification); Pembelajaran (Instructional Technique); Berbasis Hubungan (Relationship-based); dan Praktek Langsung (Direct Instruction) (Campbell dan Campbell dalam Depdiknas, 2007); serta berbagai media. Menurut Kusumo (2016), media yang dapat digunakan meliputi child size real objects, dan alas kegiatan. Child size real objectsadalah penggunaan barang-barang asli yang terbuat dari gelas, keramik, kayu, atau metal. Sementara alas kegiatan digunakan untuk memberikan batasan pada area anak melakukan kegiatan.

Penanaman kemandirian akan lebih memberikan hasil maksimal jika diberikan kepada anak sejak dini. Dengan menggunakan teori Erik H. Erikson yang melihat perkembangan anak berdasarkan teori psikososial, dimana terdapat tahapan autonomy vs 
shame and doubt, pendidik harus dapat memanfaatkannya dengan memberikan berbagai kegiatan bermanfaat sehingga yang akan tumbuh adalah autonomy bukan sebaliknya shame and doubt. Tahapan tersebut terjadi pada usia 2-3 tahun dan akan berlanjut pada tahapan selanjutnya yaitu initiative vs guilt pada usia 3-5 tahun. Adanya kemandirian yang dimiliki anak akan membuat anak memiliki inisiatif untuk menyelesaikan tugasnya tanpa perlu menunggu untuk mendapatkan bantuan dari orang di sekitarnya.

Pelaksanaan penanaman kemandirian melalui kegiatan practical life untuk anak usia kelompok bermain telah dilaksanakan di Kelompok Bermain/ Taman Kanak-Kanak Islam Al Azhar 17 Bintaro, Tangerang Selatan. Keberhasilan dalam penanaman kemandirian dapat diketahui dari kemampuan yang ditunjukkan 19 anak dari 22 anak usia 3-4 tahun. Beberapa kemampuan yang terlihat adalah mampu menuang air kedalam gelas takar, menyiapkan alat makan, membuka dan menutup pintu dengan baik, serta memakai kaus kaki, sepatu, dan tas sendiri.

Melihat kemampuan tersebut, dapat dikatakan bahwa kemandirian yang diraih anak usia 3-4 tahun di KB/ TK Al Azhar Bintaro telah setara dengan kemandirian yang harus dimiliki anak usia 5-6 tahun, yaitu dapat melakukan kegiatan yang menunjukan anak mampu terampil menggunakan tangan kanan dan kiri dalam berbagai aktivitas seperti, mengancingkan baju, menali sepatu, menggambar, menempel menggunting, makan. Sedangkan kemandirian yang harus dicapai anak usia 3-4 tahun adalah mampu menggunakan anggota tubuh untuk pengembangan motorik kasar dan halus dengan indikator anak dapat melakukan kegiatan yang menunjukan mampu menuang air atau bendabenda kecil kedalam wadah dengan tidak tumpah (Kompetensi Dasar no. 4.3); dan mampu menyelesaikan masalah sehari-hari secara kreatif dengan indikator anak dapat melakukan usaha untuk menyelesaikan kegiatan secara mandiri (Kompetensi Dasar no. 4.5) (Permendikbud No. 146 tahun 2014).

Berdasarkan capaian yang dimiliki anak usia 3-4 tahun dalam kemampuan kemandiriannya, maka tujuan dilakukannya penelitian ini adalah untuk menggambarkan pelaksanaan kegiatanpractical life sebagai upaya dalam menanamkan kemandirian pada anak usia 3-4 tahun serta penilaiannya.

\section{METODE PENELITIAN}

Penelitian yang dilakukan di KB/TK Islam $\mathrm{Al}$ Azhar 17 Bintaro ini menggunakan metode kualitatif, dengan pendekatan deskriptif dalam waktu 3 bulan sejak Januari sampai Maret 2021. Subjek penelitian adalah Kepala Sekolah, 2 Guru Kelompok Bermain dan 22 murid KB Makkah 1 Al Azhar 17 Bintaro. Teknik pengumpulan data yang digunakan adalah observasi, wawancara dan dokumentasi, dengan analisis data menggunakan Model Interaktif dari Miles and Huberman (Sugiyono, 2011), mencakup reduksi data, penyajian data dan verifikasi data.

\section{A. Hasil Penelitian}

Penelitian dilakukan pada tiga aspek utama yaitu perencanaan, pelaksanaan, dan penilaian. Masingmasing aspek dipaparkan berikut ini.

\section{Perencanaan Kegiatan}

Kegiatan yang diberikan tercantum dalam perencanaan pembelajaran baik rencana pembelajaran mingguan maupun rencana pembelajaran harian.

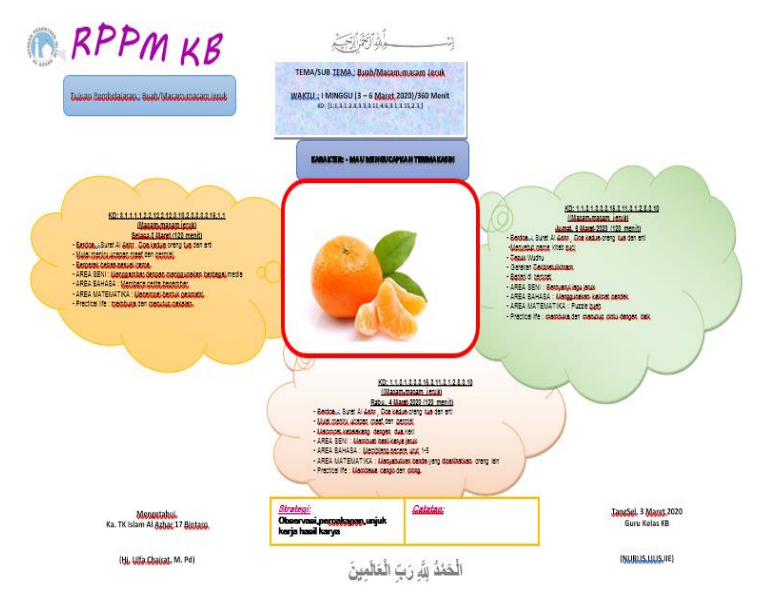

Gambar 1. RPPM untuk kegiatan practical life

Berdasarkan RPPM di atas terlihat pada terdapat perencanaan pelaksanaan kegiatan practical life pada hari Selasa (warna orange) adalah membuka dan menutup pakaian, pada hari Rabu (warna pink) adalah membawa cangkir dan piring, dan pada hari Jumat (warna hijau) adalah membuka dan menutup pintu dengan baik. 


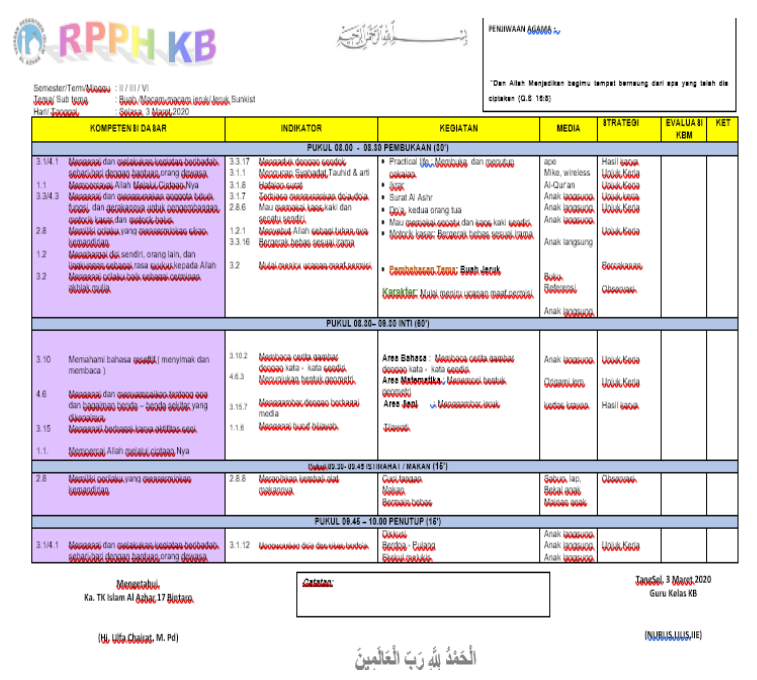

Gambar 2. RPPH untuk kegiatan practical life

Gambar 2 di atas merupakan RPPH untuk hari Selasa dengan kegiatan practical life membuka dan menutup pakaian.

\section{Pelaksanaan Kegiatan}

Observasi mendalam dilakukan selama tiga hari untuk mengetahui pelaksanaan kegiatanpractical lifeyang diberikan guru kepada anak usia 3-4 tahun. Berikut dipaparkan hasil observasi tersebut.

Selasa, 3 Maret 2020

Materi pembelajaran practical life yaitu membuka dan menutup bingkai pakaian dengan tujuan untuk melatih kemandirian anak dalam memakai baju dan celana sendiri serta mengasah kemampuan motorik halus.Adapun media yang digunakan berupa alas kegiatan dan tiga macam bingkai pakaian seperti kancing besar, resleting, dan perekat.

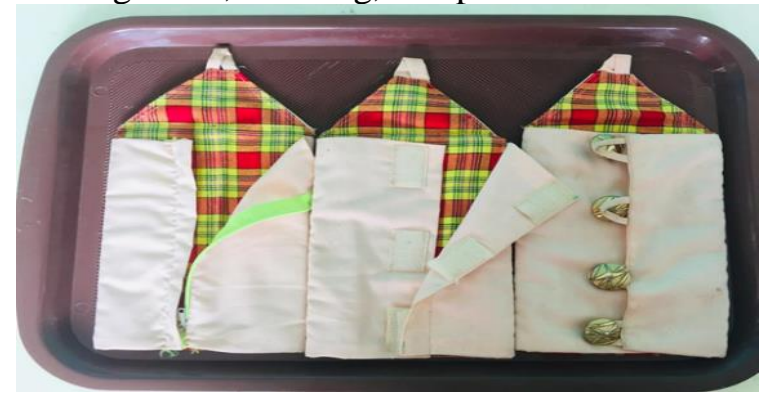

Gambar 3. Media bingkai pakaian

Sebelum melakukan kegiatan membuka dan menutup bingkai pakaian, anak terlebih dahulu mengambil sendiri media yang digunakan sesuai dengan prinsip pembelajaran practical life yaitu ambil, mainkan, rapikan.

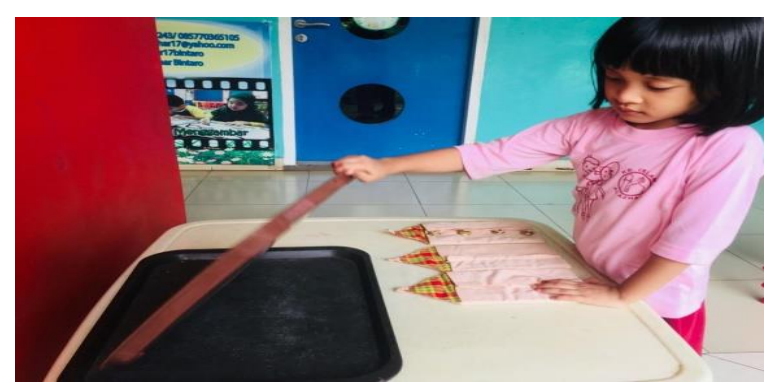

Gambar 4. Mengambil media bingkai pakaian

Pembelajaran membuka dan menutup bingkai pakaian menggunakan metode praktek langsung yang diajarkan secara bertahap agar anak dapat lebih mudah memahaminya.

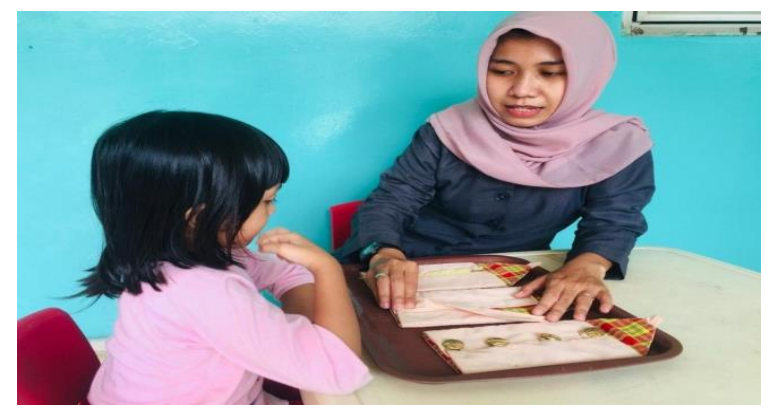

Gambar 5. Metode praktek langsung membuka dan menutup bingkai pakaian

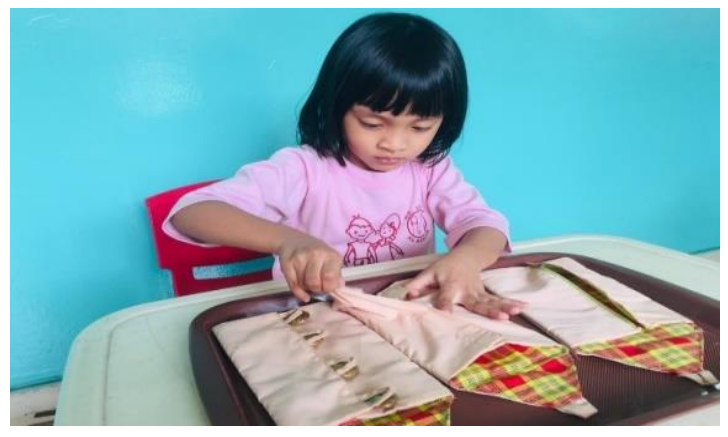

Gambar 6. Praktek membuka dan menutup bingkai pakaian

Setelah guru mempraktekan dan menjelaskan cara memainkannya, anak mencoba satu persatu media bingkai pakaian dimulai dari mengancing kancing besar, membuka dan merekatkan kembali perekat pakaian, kemudian membuka dan menutup ritsleting. Dalam memainkannya, anak melakukannya dengan menggunakan kekuatan kedua tangannya.

Rabu, 4 Maret 2020

Materi pembelajaran practical life yaitu membawa cangkir dan piring dengan tujuan untuk melatih 
konsentrasi, keseimbangan, dan kemandirian dalam membawa perlatan minum.Adapun media yang digunakan berupa alas kegiatan, cangkir dan piring keramik agar anak dapat mencoba benda-benda sesungguhnya yang dipakai setiap hari.

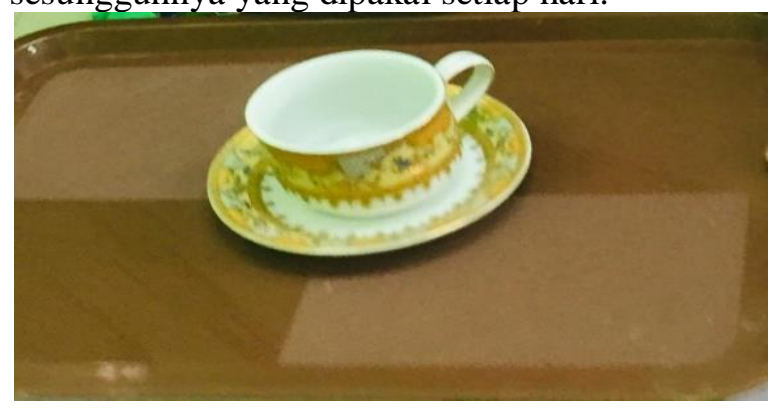

Gambar 7. Media cangkir dan piring

Pembelajaran practical life membawa cangkir dan piring menggunakan metode praktek lansung agar anak dapat melihat langsung bagaimana cara menggunakannya dan dilaksanakan di dalam ruangan kelompok bermain. Karena cangkir dan piring terbuat dari keramik maka kegiatan ini harus dialaskan karpet puzzle dengan ketebalan limacentimeter sehingga jika cangkir dan piring jatuh tidak menjadi pecah. Namun dapat juga digunakan alas berupa baki atau nampan.

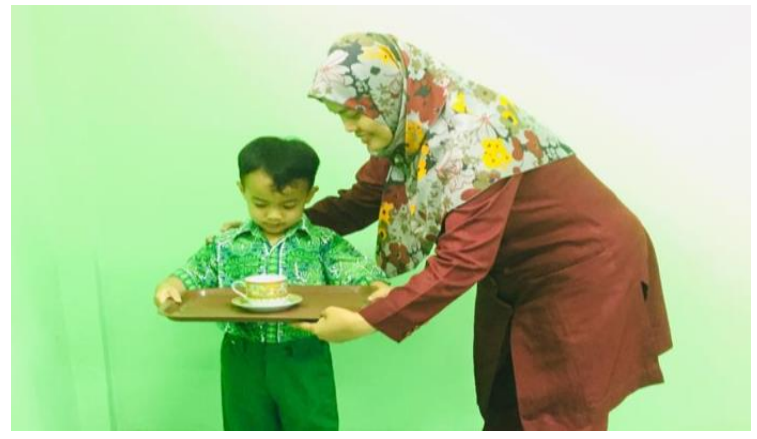

Gambar 8. Metode praktek langsung

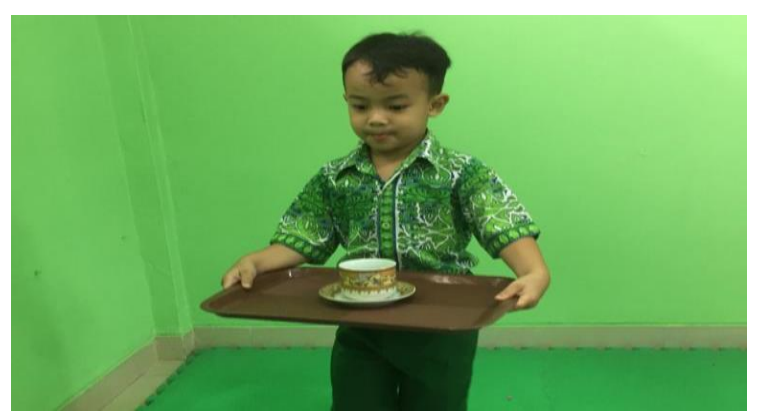

Gambar 9. Praktek membawa cangkir dan piring

Sesudah ibu guru menjelaskan dan mempraktekkan, anak diberi kesempatan untuk memegang nampan dan mencoba membawanya. Kegiatan tersebut dilakukan anak dengan pendampingan guru, seraya berpesan untuk membawanya dengan hati-hati agar cangkir dan piring tidak terjatuh.

Jumat, 6 Maret 2020

Materi pembelajaran practical life yaitu membuka dan menutup pintu dengan baik yang bertujuan untuk melatih kemampuan kemandirian anak dan membantu dirinya sendiri baik disekolah maupun dirumah dengan membuka dan menutup pintu secara baik.Adapun media yang digunakan yaitu pintu kelompok bermain.

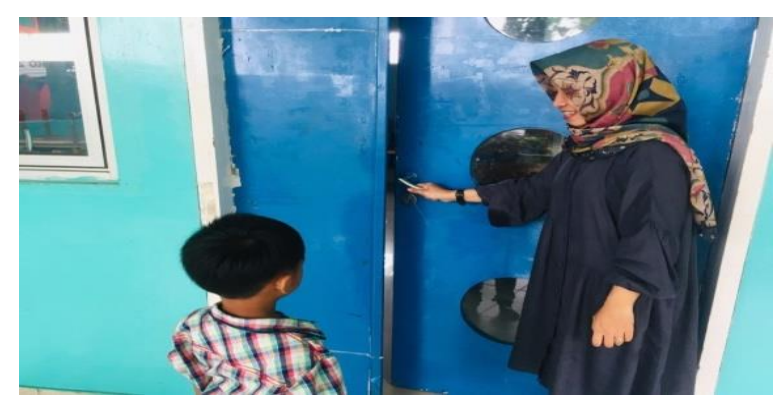

Gambar 10. Metode praktek langsung

Pembelajaran tersebut menggunakan metode praktek langsung yang diajarkan secara bertahap.Metode ini dilakukan dengan mempraktekkan langsung kepada anak.Dengan metode ini, ibu guru menjelaskan kepada anak untuk memegang gagang pintu menggunakan tangan kanan.Kemudian turunkan gagang pintu kebawah dan membuka pintu menggunakan tenaga.Begitupun ketika menutup pintu, pegang gagang pintu dan ditahan kebawah, kemudian didorong pelan-pelan sampai pintunya rapat.

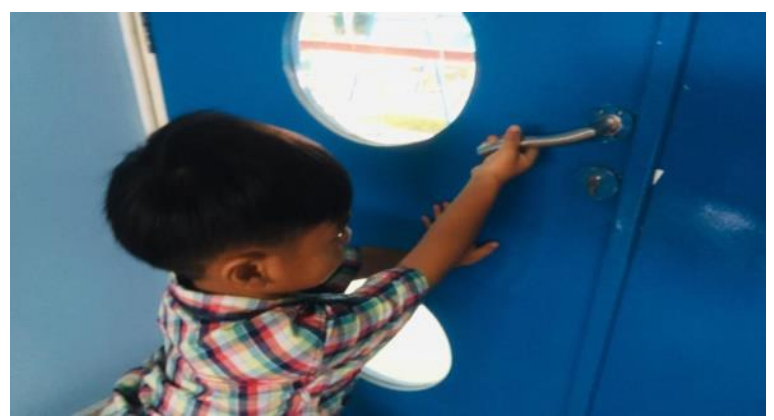

Gambar 11. Praktek membuka dan menutup pintu dengan baik

Sesudah menjelaskan dan mempraktekkannya. Ibu guru meminta anak untuk mencoba melakukannya. Kemudian, anak mencobanya dimulai dengan membaca basmalah, anak pun membuka pintu menggunakan kedua tangannya dibantu dengan 
menggunakan kekuatan kedua kakinya untuk membukanya.

Berdasarkan hasil observasi pada tiga kegiatan practical life yang diberikan, dapat disampaikan bahwa kegiatan membuka dan menutup pakaian menggunakan kancing mengharuskan anak melihat kancing serta lubang kancingnya agar setiap kancing dapat masuk ke dalam lubang yang sesuai. Hal ini membutuhkan konsentrasi yang cukup tinggi terutama bagi anak usia 3-4 tahun. Ketelitian juga diperlukan, apabila anak tidak ingin pakaiannya terlihat miring karena salah memasukkan kancing. Kesabaran juga dapat dibentuk melalui kegiatan ini, karena anak harus memasukkan kancing satu persatu ke dalam lubang kancing. Kemampuan anak menggunakan jarijarinya untuk menyelesaikan tugas menggunakan media bingkai pakaian dengan kancing, resleting, dan perekat tentu akan meningkatkan kemampuan motorik halusnya.

Kegiatan membawa cangkir dan piring menggunakan nampan tidak hanya dapat membentuk kemandirian anak, tetapi juga dapat meningkatkan kemampuan motorik kasarnya, dimana anak harus menahan beban yang ada menggunakan kedua tangan kemudian membawanya ke tempat yang ditentukan. Sikap kehati-hatian dan juga konsentrasi diperlukan agar anak dapat menyelesaikan tugasnya tanpa menjatuhkan gelas yang ia bawa. Kemampuan anak menyelesaikan tugas ini juga akan menumbuhkan kepercayaan dirinya, karena ada rasa puas atas keberhasilan yang dicapai anak. Hingga pada akhirnya anak akan semakin mandiri karena yakin bahwa ia mampu melakukan tugas-tugasnya dengan baik meskipun tanpa bantuan orang lain

Kemandirian yang ditanamkan melalui kegiatan membuka dan menutup pintu bertujuan agar anak mampu melakukannya sendiri baik pintu kelas maupun pintu rumahnya tanpa harus menunggu oranglain untuk membukakannya. Kegiatan membuka dan menutup pintu dengan baik juga dapat diartikan dengan membuka secara perlahan dan tanpa menimbulkan suara gaduh dapat melatih anak untuk mengendalikan dirinya. Averill dalam Ghufron \& Risnawati (2011) menuliskan bahwa mengendalikan diri atau kontrol diri adalah kemampuan individu untuk memodifikasi perilaku, kemampuan individu dalam mengelola informasi yang diinginkan dan yang tidak diinginkan, dan kemampuan individu untuk memilih salah satu tindakan berdasarkan sesuatu yang diyakini. Anak harus mengetahui bahwa suara keras yang ditimbulkan dari pintu yang dibuka atau ditutup akan mengganggu orang lain terutama yang berada di dalam rumah atau di dalam kelas. Sehingga melalui kegiatan ini diharapkan agar anak akan memilih untuk melakukannya dengan perlahan agar tidak mengganggu oranglain.

Keberhasilan anak dalam menyelesaikan tugas membuka dan menutup pakaian; membawa cangkir dan piring menggunakan nampan; serta membuka dan menutup pintu dengan baik tentu tidak terlepas dari metode yang digunakan guru, dalam hal ini metode praktik langsung. Melalui metode ini, guru telah memberikan pengalaman dengan melibatkan anak secara aktif dalam manipulasi objek untuk menambah pengetahuan atau pengalaman (Thobroni, 2015). Dengan melakukannya sendiri, anak mendapatkan kesempatan untuk terus mencoba apabila mengalami kegagalan. Melalui praktek langsung juga anak mengetahui bagaimana melakukan hal yang benar.

Kegiatan dengan praktek langsung dapat dilakukan menggunakan objek baik makhluk hidup maupun benda mati (Husaini, 2009) Penggunaan media berupa bingkai pakaian menjadi media yang tepat untuk melatih kemampuan anak membuka dan menutup pakaian sebelum pada akhirnya nanti anak menerapkannya langsung pada saat berpakaian. Demikian pula dengan kegiatan membawa piring dan gelas dengan nampan menggunakan media sesungguhnya tentu memberi perasaan berbeda ketika anak melakukannya dengan media tiruan. Gordon dan Browne (2014) mengungkapkan bahwa in the practical life area, children imitate adults activities, such as pouring and food preparation, but with real glasses, pitchers, and utensils readily available to them. Hal ini dapat menjadikannya untuk hati-hati agar benda yang dibawanya tidak jatuh apalagi sampai pecah.

\section{Penilaian Kemandirian}

Penilaian terhadap kemandirian yang dimiliki anak melalui kegiatan practical life dilakukan setiap hari, setelah kegiatan belajar mengajar selesai. Penilaian tersebut berupa observasi dengan checklist dan catatan harian, yang dikumpulkan kepada kepala sekolah setiap satu minggu sekali. Pada penilaian checklist, berisi indikator pencapaian perkembangan anak, kegiatan yang sesuai dengan RPPM dan RPPH, dan nomor absen anak dengan rubrik penilaian jika anak mengerjakannya dengan bantuan maka mendapat nilai "bulat checklist", dan 
jika anak dapat mengerjakannya sendiri mendapat nilai"checklist". Selain itu, pada penilaian catatan harian berisi tabel berjumlah 22 anak. Setiap tabel terdapat nama anak sesuai urutan absen. Guru kelompok bermain menilainya dengan cara mengisi narasi sesuai dengan kejadian setiap harinya.

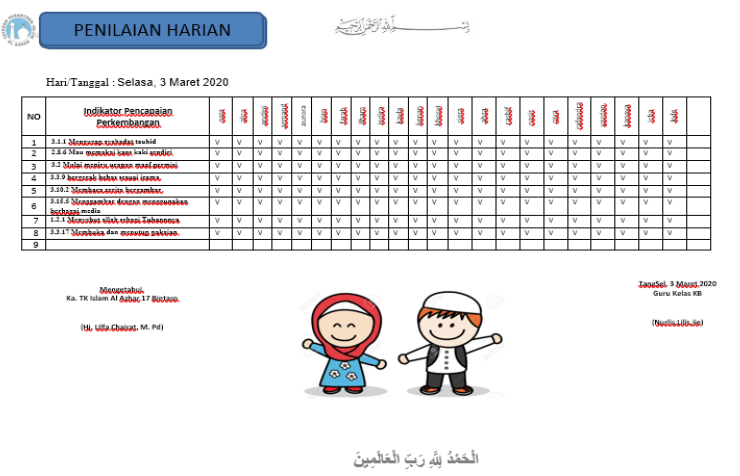

Gambar 12. Hasil penilaian kegiatan practical life

Selain penilaian harian, setiap tiga bulan sekali ada pergantian term atau tema.Sesudah kegiatan puncak tema, guru memberikan buku penilaian berupa rapot kepada orangtua.Hasil pembelajaran practical life diisi pada tabel aspek perkembangan fisik motorik dan sosial emosional berupa foto dan narasi perkembangan anak.

Melakukan penilaian dari kegiatan yang telah diberikan perlu dilakukan untuk mengetahui apakah sebuah kegiatan atau program yang diberikan kepada anak memberikan dampak positif pada pencapaian kemampuan anak tersebut. Penilaian menjadi penting dilakukan untuk mengetahui seberapa besar dampak program pendidikan terhadap perilaku dan sikap, baik jangka pendek, jangka menengah maupun jangka panjang (Mulyasa, 2012).

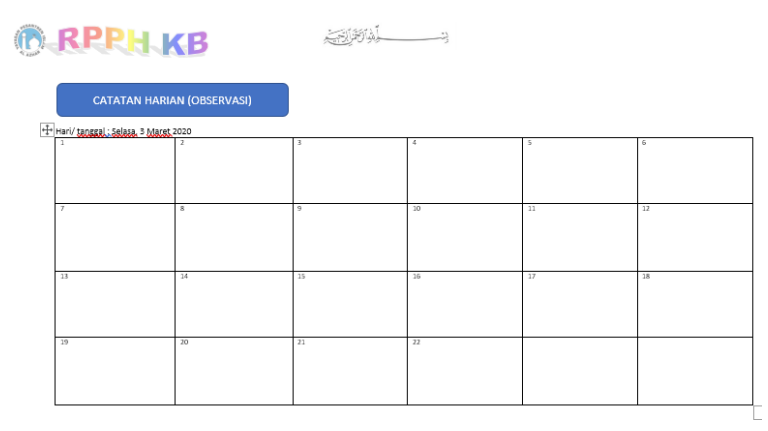

Gambar 13 Form penilaian catatan harian kegiatan practical life
Penilaian dalam pendidikan anak usia dini terdiri dari berbagai jenis, satu diantaranya adalah penilaian dengan teknik observasi. Wolfgang \& Wolfgang (1992: 213) menuliskan bahwa "the primary assessment tool of the play-activity (childcentered) curriculum is the direct observation of children." Penggunaan observasi dapat membantu guru untuk melihat dan memahami kemajuan anak didiknya. Dengan melakukan observasi sebagai alat penilaian, guru dapat melihat banyak hal dalam diri anak terkait dengan perkembangan dan kemampuannya (Rohita \& Nurfadilah, 2017), termasuk kemampuan dalam menyelesaikan tugastugas untuk melatih kemandirian anak. Adanya penilaian yang diberikan dalam bentuk narasi, akan memberikan gambaran lebih jelas baik bagi guru itu sendiri maupun bagi orangtua mengenai kemampuan yang telah ditunjukkan anak.

Penilaian yang dilakukan secara bertahap mulai penilaian harian dan penilaian tiga bulanan, menggunakan dua bentuk penyajian yaitu ceklis dan narasi menunjukkan bahwa terdapat konsistensi dan komitmen dari pihak sekolah dalam upaya penanaman kemandirian anak melalui kegiatan practical life. Dan, sekaligus menunjukkan bahwa penilaian yang dilakukan telah sesuai dengan prinsip penilaian, yaitu dilakukan secara terus menerus (Suyanto, 2005).

\section{SIMPULAN DAN SARAN}

Berdasarkan penelitian yang telah dilakukan, dapat disimpulkan bahwa kemandirian dapat ditanamkan kepada anak usia 3- 4 tahun melalui kegiatan practical life, diantaranya berupa membuka dan menutup pakaian; membawa gelas, piring, dan nampan; serta membuka dan menutup pintu, yang diberikan saat anak datang ke sekolah sebelum pembelajaran dimulai. Kegiatan diberikan menggunakan metode praktek langsung dengan media benda sesungguhnya.

Adapun saran yang dapat diberikan untuk meningkatkan kemandirian anak diantaranya adalah pertama, dengan memberikan penguatan dan reward terhadap apa yang dilakukan oleh anak di sekolah, sehingga anak dapat lebih termotivasi ketika melakukan kegiatan practical life; dan kedua, guru bekerjasama dengan orangtua untuk memberikan kegiatan practical life selama anak di rumah sehingga kemampuan yang diajarkan tertanam dalam diri anak sehingga anak dapat melakukan lebih banyak kegiatan secara mandiri. 


\section{DAFTAR PUSTAKA}

Departemen Pendidikan Nasional.(2007). Pedoman Pembelajaran Bidang Pengembangan Pembiasaan Di Taman Kanak-Kanak. Seri 1. Jakarta.

Gordon, A., \& Browne, K. (2014). Beginnings \& beyond: Foundations in early childhood education nineth edition. USA: Wadsworth

Gufron, M.N., \& Risnawati, R.(2010).Teori-Teori Psikologi. Yogyakarta: Ar-Ruzz Media.

Houver, J.D., Holmes, D.B., \& Moors, A. (2013). What is learning? On the nature and merits of a functional definition of learning.Psychonomic Bulletin \& Review. 20(4). 1-18.DOI: 10.3758/s13423-013-0386-3

Kusumo, E.L. (2016). Montessori Di Rumah. Jakarta: Esensi Erlangga Group.

Larasati, T.D. (2018).Pengaruh Model Pembelajaran Practical life Terhadap Kemandirian Mengurus Diri Pada Anak Usia Dini (Penelitian di KB 'Aisyiyah Budi Mulia Kalibening Kecamatan Dukun Kabupaten Magelang. Skripsi. Universitas Muhammadiyah Magelang.

Mulyasa.(2012). Manajemen PAUD. Bandung: Remaja Rosdakarya.

Morrison, G. S. (2011). Dasar-Dasar Pendidikan Anak Usia Dini. Jakarta: Indeks.

Noordianti. (2018).Asuhan Kebidanan, Neonatus, Bayi, Balita Dan Anak Pra Sekolah. Malang: Wineka Media.

Parinduri, E. (2012).Studi Identifikasi Motivasi Orangtua Menyekolahkan Anaknya Ke Preschool Di Taman Kanak-Kanak Panca Budi.Skripsi. Universitas Medan Area.
Peraturan Menteri Pendidikan Dan Kebudayaan No. 137 Tahun 2014 tentang Standar Nasional Pendidikan Anak Usia Dini. Jakarta.

Peraturan Menteri Pendidikan Dan Kebudayaan No. 146 Tahun 2014 tentang Standar Nasional Pendidikan Anak Usia Dini. Jakarta.

Rantina, M. (2015).Peningkatan Kemandirian Melalui Kegiatan Pembelajaran Practical life (Penelitian Di TK B Negeri Pembina Kabupaten Lima Puluh Kota).Jurnal Pendidikan Usia Dini. 9(1).181-

200.DOI: https://doi.org/10.21009/JPUD.091.11

Rohita \& Nurfadilah. (2017). Pelaksanaan Penilaian Pembelajaran di Taman KanakKanak (Studi Deskriptif pada Taman Kanak-kanak di Jakarta).Jurnal Al-Azhar Indonesia Seri Humaniora, 4(1).53-62. DOI: http://dx.doi.org/10.36722/sh.v4i1.255.

Suyanto, Slamet. (2005). Pembelajaran untuk Anak TK, Depdiknas Dirjen Dikti Dir. Pembinaan Pendidikan Tenaga Kependidikan. Jakarta

Thobroni, M. (2015). Belajar dan Pembelajaran: Teori dan Praktek. Yogjakarta: Arr-Ruzz Media.

Wolfgang, C.H., \& Wolfgang, M.E. (1992).School for Young Children. Developmentally Appropriate Practice. USA: Allyn \& Bacon.

Yamin, M., \&Sanan, J.S. (2012).Panduan Pendidikan Anak Usia Dini. Jakarta. 